\title{
Genetic disease in the family: trajectories and experiences in
} public health services ${ }^{a}$

\author{
Doença genética na família: trajetórias e experiências em serviços públicos de saúde \\ Enfermedad genética en la familia: trajetorias y experiencias en servicios públicos de salud
}

Laura Helena Gerber Franciscatto ${ }^{1}$ (C) Mara Regina Santos da Silva ${ }^{1}$ Alessandro Marques dos Santos ${ }^{2}$ (1) Adriane Maria Netto de Oliveira ${ }^{1}$ (D) Keterlin Salvador ${ }^{3}$ (D)

1. Universidade Federal do Rio Grande, Escola de Enfermagem, Programa de Pós-Graduação em Enfermagem. Rio Grande, RS, Brasil. 2. Universidade Católica de Pelotas.

Pelotas, RS, Brasil.

3. Universidade Regional Integrada

do Alto Uruguai e das Missões.

Frederico Westphalen, RS, Brasil.
Corresponding author:

Laura Helena Gerber Francisacatto.

E-mail: laura.gerber.franciscatto@gmail.com

Submitted on $04 / 18 / 2019$

Accepted on 08/20/2019.

DOI: 10.1590/2177-9465-EAN-2019-0128

\section{Abstract}

Objective: To identify the trajectories and experiences of families of children with genetic diseases in health services. Method A qualitative study, with data collected through interviews with 15 families and caregivers of children with Genetic Disease, living in the northern region of Rio Grande do Sul. Interviews were conducted from March to May 2018. Data analysis was based on thematic analysis. Results: A genetic disease diagnosis led to families' changes due to the demands of treatment, and also the needs of the child for being met by health services. To access specialized services, some families needed to travel to referra centers in larger cities. Families experienced difficulties such as unprepared health professionals, lack of organization of services, judicialization of resources, and need for structured Health Care Networks. Conclusion: The professional has the fundamenta role of providing families with access to information and are responsible for decision making and for the organization and management of health and nursing services to meet the demands imposed on the individual and the family by the genetic disease.

Keywords: Genetics; Nursing; Health services; Family; Qualitative Research.

\section{RESUMO}

Objetivo: Identificar trajetórias e experiências em serviços de saúde de famílias que possuem filhos com doenças genéticas. Método: Estudo de abordagem qualitativa, cujos dados foram coletados por meio de entrevistas com 15 famílias representadas pelas mães cuidadoras que possuem filhos com Doença Genética, residentes na região norte do Rio Grande do Sul, de março a maio de 2018. A análise dos dados ocorreu através da análise temática. Resultados: O diagnóstico da doença genética acarretou mudanças nas famílias, pela procura de tratamento junto aos serviços de saúde para atender as necessidades do filho. Para ter acesso a serviços especializados, algumas famílias precisaram deslocar-se para centros de referência em cidades maiores. As famílias vivenciaram dificuldades como despreparo dos profissionais de saúde, falta de organização dos serviços, processos de judicialização dos recursos e necessidade de Redes de Atenção à Saúde estruturadas. Conclusão: O profissional enfermeiro assume papel fundamental para prover às famílias o acesso à informação, à tomada de decisão e à organização da gestão e do gerenciamento dos serviços de saúde e de enfermagem para atender às demandas que a doença genética condiciona ao indivíduo e à família.

Palavras-chave: Genética; Enfermagem; Serviços de saúde; Família; Pesquisa qualitativa.

\section{Resumen}

Objetivo: Identificar trayectorias y experiencias en servicios de salud de familias que poseen hijos con enfermedades genéticas Método: Estudio de abordaje cualitativo, cuyos datos fueron recolectados por medio de entrevistas con 15 familias representadas por las madres cuidadoras que poseen hijos con enfermedad genética, residentes en la región norte de Rio Grande do Sul, de marzo a mayo de 2018. El análisis de los datos ocurrió a través del análisis temático. Resultados: El diagnóstico de la enfermedad genética trajo cambios en las familias, por la demanda de tratamiento junto a los servicios de salud para atender a las necesidades del hijo. Para acceder a servicios especializados, algunas familias necesitaban desplazarse a centros de referencia en ciudades más grandes. Las familias experimentaron dificultades como la falta de preparo de los profesionales de salud, falta de organización de los servicios, procesos de judicialización de los recursos y necesidad de Redes de Atención a la salud estructuradas. Conclusión: El profesional enfermero asume un papel fundamental para proporcionar a las familias acceso a la información, a la toma de decisiones y a la organización de la gestión y gestión de los servicios de salud y enfermería para satisfacer a las demandas que las enfermedades genéticas condicionan al individuo y a la familia.

Palabras clave: Genética; enfermería; Servicios de salud; Familia; Investigación Cualitativa. 


\section{INTRODUCTION}

Around 7.6 million children worldwide are born each year with genetic and congenital malformations, of which $90 \%$ are in low- and middle-income countries. In developed countries, these diseases are the second leading cause of child mortality in children under one year of age, with a prevalence of 25 - 60 per 1,000 births. ${ }^{1,2}$

Congenital and genetic disorder have become relevant for public health as they account for $20 \%$ of deaths in children under one year old, exceeding the total sum of the third and fourth causes of death, which are respectively related to respiratory and infectious diseases. In addition, congenital and genetic disorders account for more than one third of all pediatric hospitalizations in some care hospitals in Brazil. ${ }^{2}$

Genetic diseases (GDs) are characterized by being chronic and progressive, and usually lead to changes in family life, as families need to restructure their daily lives to care for the sick child. Usually, the family is not prepared for the diagnosis of a long-term and incurable disease in one of its members. ${ }^{3}$

Undoubtedly, the family builds a connection with the health services, as most GDs lead to motor, cognitive, emotional or other limitations, and the patient may require follow up at different levels of care (primary, secondary and tertiary) for a very long period, usually for years. In cases of evolving chronic diseases in children, health services are a strong part of their support and treatment network. ${ }^{4}$

Coping with a GD can have important implications for the family. Health institutions are not always prepared to meet their needs. In their search for help, families face lack of information about the disease, difficulty in accessing diagnosis and treatment, lack of teams with qualified health professionals, and shortage of referral centers in genetic health care..$^{4,5}$

The way the family is supported when a GD is diagnosed interferes with the experience of coping with the disease. When they interact with health professionals who provide support and enlightenment, mothers feel safe to take on the care, as they feel stronger with the reception and empathy received. Professionals must help families recognize their strengths and potential, as well as their weaknesses and needs, supporting and equipping them so that they can take care of their family members in the best way possible. ${ }^{6}$

In order to provide institutional support to families with a GDs, the National Policy for Comprehensive Attention in Clinical Genetics (PNAIGC) was instituted in 2009, with the purpose of organizing a network of services for the promotion, prevention, diagnosis, counseling and treatment of GDs. In addition, this policy was intended to be incorporated and implemented by SUS at all levels of care, articulating the primary care network with prevention and identification of cases to be referred to specialized care..$^{2,7-10}$ Above all, this Policy had the purpose of structuring, within the SUS, a regionalized and hierarchical system that would provide comprehensive care in clinical genetics and improve access to specialized services.

Regarding the organization of care for rare disease patients, the National Policy on Comprehensive Care for People with Rare Diseases (PNAIPDR) was approved in 2014 and is structured on two major axes: Axis I - composed of genetic rare diseases and organized into the following groups: a) late-onset or congenital anomalies; b) intellectual disability; and c) inborn errors of metabolism; and Axis II - composed of non-genetic rare diseases and organized into the following groups: i) infectious; ii) inflammatory; and iii) autoimmune. The care system for users of the PNAIPDR is structured by Primary Health Care and Specialized Care. ${ }^{11}$

The way and the rapidity with which new genomic knowledge with potential to be applied in care is discovered creates a new model of health care and give new meanings to genomic health care, which is the process of gene-based diagnosis, prevention and therapy. This process considers the manifestations of health and illness as a result of the combinations between the human genome and the influences of external and internal environment. Thus, to meet the new demands of care, these advances must be included in nursing care. ${ }^{12}$

Therefore, nurses, based on their competences and as leaders of the health team, must be imbued with scientific knowledge in genetics and genomics, so that they can provide quality care, integrating this knowledge into clinical practice in the current Postgenomic Era.

Genetic researchers point out factors that can support nursing practice in this context, such as the development of activities related to care, education, management and research. A nursing competence that stands out is the nursing consultations, in which they can obtain and evaluate genetic family history of at least three generations, incorporate technologies and information in genetics and genomics in their work practice, pass on correct, credible, and up-to-date information on existing resources and services, assess knowledge, perceptions and responses of the client to the information provided, facilitating its interpretation, and refer patients to specialized services. ${ }^{13,14}$

The question that guided this study was: What are the paths taken by families of people with GD searching for help in public health services? Thus, the objective of this study was to identify the trajectories and experiences of families of children with genetic diseases in health services.

\section{METHOD}

Exploratory study with qualitative approach. This approach focuses on opinions, beliefs, values, representations, relationships, and actions, based on the participants' point of view and the meaning they attribute to their experiences. ${ }^{15}$ 
The participants were 15 mothers and caregivers of children with Genetic Diseases (GDs). Participants were selected in the Association of Parents and Friends of the Exceptional (APAE) of a city in the northern region of Rio Grande do Sul, Brazil. The inclusion criteria of the study were: 1) being a father, mother and/or close family member of the individual with GD; 2) the individual with diagnosis of a GD being over two years old; 3 ) the individual with diagnosis of a GD be attending APAE; 4) family members being over 18 years old. Exclusion criteria: Participants who, for health reasons, did not attend APAE during the data collection period were excluded from the study; there was only one exclusion

The sample was defined by convenience; APAE professionals indicated mothers who would be available and interested in participating in the research. The number of participants was defined by data saturation. ${ }^{16}$ The definitive inclusion of families in this research occurred only after the participants expressed agreement by signing the Informed Consent Form (TCLE).

Data were collected between March and May 2018, through semi-structured interviews, which were recorded with the consent of the participants. Data collection was based on a semi-structured interview script composed of a guiding question. "How does access to health services/referral centers occurs for your family?". An audio recorder was used to record the data. The interviews were transcribed in full for content analysis. To preserve anonymity, families are identified by a code formed by the letter $F$ (family) followed by the number of their interview ( $F 1$, F2, F3, F4, F5... and F15).

The interviews occurred at APAE and at the participant's home, according to the availability of the mothers/caregivers and established in a previous appointment by telephone. The telephone contact of the mothers/caregivers was provided by APAE. None of the mothers contacted refused to participate in the study. Even though some interviews were conducted at the families' homes, other family members were not present. The interviews were conducted with the presence only of the mothers/ caregivers and the researchers. Each interview was conducted individually and in the presence of one or two of the researchers. The average duration of the interviews was 30 minutes. None of the researchers had previously been part of the APAE service or had had any previous relationship with the participants.

Among the families that were part of the study, eight lived in the urban area and seven in the rural area. Among the mothers/ caregivers of children with GD, 11 were over 35 years old. Six of them had not completed elementary school, four had completed high school, two had completed elementary school, two had a higher education degree and one had a graduate specialization. Finally, regarding the income of the families that were part of the study, seven lived with more than two minimum wages, four with between one and two minimum wages and four with less than one minimum wage.
Among the fathers, most (five) were farmers, three were salesmen, two were businessmen and two were retired. Most of the mothers (four) were housewives, three worked in farming and three were retired. Regarding civil status, 12 couples were married. Seven of the participants had two children, five had three children and three had one child. Regarding the age of the children, six were between two and nine years old, six between 10 and 19 years old and three between 20 and 30 years old Among these children, eight were male, and seven were female.

The most prevalent GDs in this research were: Down Syndrome (nine), followed by Duchenne Muscular Dystrophy (two), Rett Syndrome (two) and Treacher Collins Syndrome (two). Dandy-Walker syndrome was also reported in one of the cases.

Data were analyzed by reading the empirical material, looking for the particularities of the speeches through the thematic analysis technique. ${ }^{17}$ Data were analyzed through the following steps: reading and re-reading the interviews; coding of information; identification of themes based on the regularities and patterns identified in the words, phrases and behaviors manifested during the interviews, resulting in two themes: Diagnostic and therapeutic journey; and Experiences of families of children with Genetic Diseases in public health services. The study was approved by the Research Ethics Committee of the proposing institution, protocol CAAE: 79500317700005324 and protocol \# 184/2017.

\section{RESULTS}

\section{Diagnostic and therapeutic journey}

This theme addresses the trajectory of families since the moment in which the child manifests the first signs and symptoms and throughout their search for the first health service, the confirmation of the diagnosis and the search for specialized services in GD.

The diagnosis of a genetic disease is a remarkable moment for parents, as from then on, the dreams and perspectives of families are changed. Understanding the diagnosis is a process with a lot of concerns, as from the moment of diagnosis, the family begins to face a new reality, very different from the one they had planned.

Statements showed that the diagnosis did not occur at birth, as the children did not have dysmorphic physical features. Thus, the suspicion of a pathology only began when observing delay in growth and development.

After the manifestation of the first signs and symptoms, the families were distressed and worried about the limitations presented by their child. This situation in described the statements of one of the mothers/caregivers:

[...] actually, she was born well, perfect. Like a normal child. Then, after a year, a year and two months, she wasn't walking, and then I got worried [...] (F3). 
[...] he said: your baby is all behind in his development, he will walk, but nobody knows when he will start walking $[\ldots]$ (F13).

All the families studied initially sought the Basic Health Unit (BHU). Ten families were referred to the pediatrician and five to the neurologist.

\section{[...] I went to the health center and then I was referred to the neurologist, everything occurred through the health center $[\ldots]$ (F8). \\ [...] we use the services of the health center for everything, consultations with pediatricians, general practitioners, vaccines, and every referral comes from the health center $[\ldots]$ (F15).}

Regarding the confirmation of the diagnosis of a GD, eleven families reported that they had a karyotype test. After the confirmation of the exam, some families felt more certain about their child's GD and were then sure that they had the correct diagnosis. After this finding, they began their search for specialists in the area of genetics. Some mothers/caregivers expressed resignation after the genetic examination.

[...] we had that hope that it was not it, but after some days you realize that it actually is. And then when the [karyotype] test came, it was more for confirmation [...] (F2).

[...] the family, at that time, they didn't want to accept, it was like: Oh no, he has nothing. But then the exam confirmed it. Then we must accept it. There is nothing else to do [...] (F14).

It was evidenced that, after the diagnosis, the health professionals responsible for the care of these families understood the need for referral to specialized services in genetics. However, in the city of the families studied, there were no specialized services in this area, so ten families were eventually sent to the state capital, where most of these services were located. At this time, these families experienced a real journey in the search for treatment and monitoring of GD, as shown in the following statements:

[...] I went to a health center, which sent me first to the neurologist, then everything was referred by the health center and then I started genetic, now I'm just in the Hospital de Clínicas [...] (F8).

$[\ldots .$.$] It was in the health post center that we were able to get$ a referral to the Hospital de Clínicas, in genetics [...] (F3).
One of the main difficulties faced by five families was having to travel long distances for treatment. These families stressed the need for easier access to these resources and understood the importance of having closer referral services and more specialized professionals, as it can be observed in the speech of three mothers/caregivers:

[...] we went a lot to Porto Alegre, through the SUS [...] But it wasn't easy to leave at midnight and get there at 6 am. With a city van. Staying there all day [...] (F9).

[...] the biggest difficulties to get there are transportation and just staying there [...] you arrive at 6am and have to wait until $2 p m$ for the consultation, and this is very tiring and it irritates the child [...] (F7).

[...] I think there should be more of them (health professionals), there should me more help, more accessibility and agility [...] (F5).

In addition to specialized services in the area of genetics, another part of the trajectory of all the families was the search for an institution that would meet the needs of children with disabilities. In this context, they found support in APAE. This institution, located in the city of the present study, improved the quality of life of people with disabilities, who found support from professionals from various areas such as psychologists, physical therapists, speech therapists, educators, social workers, among others.

[...] she has been at APAE since she was seven months old, because I was told that they had a physical therapist, a speech therapist, a psychologist and that she did not have to pay [...] (F9).

\section{Experiences of families of children with Genetic Diseases in public health services}

This theme addresses the experiences lived in the health services and includes difficulties regarding the unpreparedness of health professionals, access to information, service organization and the issue related to the judicialization of health.

When faced with the diagnosis of a previously unknown disease, all the families looked for clarification on their children's health situation, prognosis, treatment and care. However, seven families reported that failures in the organization of health services and in the process of referral to specialties made them feel frustrated with the little information provided by health professionals and their lack of reliability; this is shown in the words of two mothers/caregivers:

[...] when we needed health services, I found myself completely lost. And I just thought, my God, who do I talk to, who is in charge here? Sometimes we need different 
services, different exams and no one could tell us where to find that specific doctor, that exam, and some things I had to leave behind because I didn't know where to look. The professionals didn't know how to guide me, they just told me that I had to go after things, but they didn't say where, you don't know which way to go [...] (F15).

[...] our difficulty was that neither health professionals, nor the health department knew where to send me [...] One of the difficulties was the delay in getting the right specialties to get the right treatment [...] (F4).

For two families, the judicialization process became a martyrdom. They reported their struggle in the fight for access to medication, treatment and surgical procedures. Moreover, in the statements of three mothers/caregivers, it was possible to understand the difficulty of getting something in health service through the judicial system, as it is a slow and bureaucratic process.

[...] for my daughter to get the device to do the surgery I had to make a revolution with the prosecutor, I did it and I went to the court. But that took almost a year. [...] (F4).

[...] this disease has no cure, I got the medication through the judicial system, but I was three months without the medication, I had to but it to no let him without it. [...] (F6).

[...] I spend five hundred reais a month. So, if I only earned one minimum wage I would starve, I was told to go to court, but it's a lot of paperwork. [...] (F14).

It was found that health services are below expectations in this scenario. There are failures in important factors such as lack of professionals trained for the care of GDs, and there is a need for a structured care network that offers comprehensive care in clinical genetics. This is reported by two mothers/caregivers:

[...] you can see the unpreparedness of professionals and of some health services, the SUS service does not have all specialties. The network does not work or does not appear. [...] (F4)

[...] we urgently need to have an organized care network, because we need to have foundation, we need to have support. So, you need people who have knowledge of what they are talking about [...] (F15).

\section{DISCUSSION}

Genetic disease (GD) affects the members of the family, who have to restructure their daily lives to receive and care for the sick child and who need help to provide daily and continuous care. Families mobilize, looking for all kinds of treatment, in an attempt to find services and professionals that can effectively meet their child's needs. In the current context of Brazilian health, an interdisciplinary, collective health work, with the integration of different services is recommended, so that individuals can receive comprehensive care. ${ }^{18}$

The first resource used by families when their children presented the first signs and symptoms was the Basic Health Unit (BHU). In this scenario, it is necessary to discuss the National Policy for Comprehensive Attention in Clinical Genetics (PNAIGC), which was instituted in 2009 and designates the $\mathrm{BHU}$ as responsible for performing low complexity procedures such as identification, referral and monitoring of individuals with GD. ${ }^{19}$

However, knowing that $80 \%$ of rare diseases are of genetic origin and that they affect about $8 \%$ of the world population, the lack of a broader perspective that contemplates the specificities of the different needs of rare diseases within the SUS, providing responses to these genetic disorders, has been an important barrier, hindering patients' access to adequate care. ${ }^{5,8}$ In response to these needs, the Ministry of Health proposed Ordinance GM/MS No. 199/2014, which implemented the National Policy on Comprehensive Care for People with Rare Diseases (PNAIPDR) with guidelines for comprehensive care of people with rare diseases in the SUS and offer of financial incentives for funding. ${ }^{11}$

The scope of the PNAIPDR is transversal to the priority thematic networks of SUS, in particular the Care Network of People with Chronic Diseases, the Care Network for Disabled People, the Emergency Network, the Psychosocial Care Network and the Rede Cegonha. The main objectives of this recent policy are to reduce mortality, to contribute to the reduction of morbidity and of secondary manifestations, and to improve people's quality of life, through actions of promotion, prevention, early detection, timely treatment, reduction of disability and palliative care..$^{5,11,10}$

The city of the present study, located in the northern region of Rio Grande do Sul, does not have specialized care in the area of Genetics. Therefore, families of people with GD had to travel long distances to the state capital, where the referral centers in genetics are commonly located.

In order to meet this need, the Ministry of Health instituted the Out-of-Home Treatment Program (TFD) in Ordinance No. 55/99 of the Health Care Office. The TFD aims to guarantee medical treatment through the SUS for patients with diseases that can no longer be treated in their city of origin when all means of care are exhausted. Therefore, the TFD is a funding assistance for the patient and sometimes for the companion. However, in all families of this study, this funding was not evident. ${ }^{20}$

A study ${ }^{21}$ conducted in the state of Rio Grande do Sul, aiming to characterize the diagnostic and therapeutic journey of families of patients with rare diseases, showed that they found diagnostic support and multi-professional monitoring in referral centers, usually located in the state capitals. This study also highlighted the need for qualified services close to the population that does not reside in the large centers, where the referral centers are located. ${ }^{21}$ 
The individuals of the study are followed up in the institution called Association of Parents and Friends of the Exceptional (APAE). This is a Brazilian institution that works with people with intellectual disabilities and multiple and global developmental disorders, aiming to provide a complete service to realize their physical, intellectual, affective and social potential, in a welcoming environment that is adequate to the needs of each user and that enables the work of a multidisciplinary team that can contribute to a better management of the GD. The multidisciplinary team is responsible for planning and developing unique and complementary actions, so that the assistance provided is comprehensive and meets all the needs of the children and their family. ${ }^{22}$

One of the situations experienced by families of children with GDs was the disorganization of health services, illustrated by the difficulties in referral and scheduling of appointments and poor access to information about the problem.

A study ${ }^{4}$ conducted in Rio Grande do Sul, with the objective of identifying the priority needs of families of rare disease patients, found that access to social and health services was a priority need mentioned by all families. They reported they felt powerless with the little information provided. The constant visits to health services became stressful and did not resolve their problem. The need for knowledge about the disease was also mentioned as a priority by most of the families studied, since parents often feel frustrated with the lack of knowledge among health professionals and society.

It was found that families have to rely on judicial means to ensure continuity of treatment, since medications, tests, and surgical treatment needs increase expenses in the family context. Health is recognized, in national and international laws, as a fundamental right that must be ensured by the government to its citizens, through public policies and actions that allow universal access and promote well-being. The right to health implies the availability of health care services and supplies, which are a social right that includes an individual and a collective dimension. ${ }^{23}$

Brazil still has several gaps in GD care, including: limited number of genetics services; shortage of trained professionals in the area; lack of genetics doctors in the SUS, which are professionals that can only be found in research institutions and universities; difficulties to access specialized services, which are concentrated in the large capitals of Brazil, hindering access of families living in smaller cities; high cost of laboratory tests; medication and difficulties in referral and counter-referral. These factors lead to a lack of care for families with GDs and deficiencies in their health needs. .,24 $^{8,24}$

The mothers of this study affirmed that the care for children with a GD should be done through a structured network specifically organized to meet the of these conditions. Historically, the field of genetics has been included in the SUS since 1989 and has evolved through the implementation of public policies aimed at people with disabilities. In addition, the recent National Policy for Comprehensive Attention in Clinical Genetics (PNAIGC) had the purpose of structuring, within the SUS, a regionalized and hierarchical system that would provide comprehensive care in Clinical Genetics and improve access to specialized services. ${ }^{19}$

In fact, the PNAIGC, which was incorporated by the PNAIPDR, represented a major advance in SUS. However, care is still far below expectations for the reality of genetic diseases, particularly in Primary Health Care (PHC). 2,5,8,10,25

Among the main barrier to the operationalization of this policy are the lack of specialized human resources and lack of instruments for the identification and care of families and/or individuals with genetic diseases, hindering the possibility of meeting this type of demand. $5,8,10$ This is partly due to the lack of focused and specialized teaching in this area in the Brazilian curriculum. ${ }^{7,10}$

In Brazil, there are few services specialized in the diagnosis of genetic diseases and in the prospective follow-up of these patients and their families. These services are mostly located in university hospitals or in private institutions that offer a high cost service, making access increasingly restricted and difficult. 2,8 In addition, these services they are located in large population centers (usually in capital cities, especially in the Southeast and South Region), further increasing difficulties in access. ${ }^{8}$

Families who need support from health services often face an arduous journey to deal with the health issues of the GD. Access and consumption of services provided to individuals with GD, or at risk of genetic conditions, have been below expectations, a clear example of the divergence between the constitutional proposal and the reality of Brazilian genetics services. ${ }^{9}$

Therefore, actions to organize initial care, diagnosis, complementary tests, referral and counter-referral services, treatment strategies and continuity of care are necessary in order to provide comprehensive care to people facing a GD. ${ }^{9}$

This article emphasizes the care provided by health professionals to people affected by GDs. In this context, it is worth mentioning and describing the performance of the professional nurse and their role as part of the multi-professional team. Nursing care begins at the first contact with the family, as the nurse is responsible for primary care and must promote comfort, reception and well-being among their patients, offering comprehensive care and promoting the autonomy of clients through health education. In this scenario, nurses must create bonds with the patient and their family, so that they can provide essential information about the physical and mental health conditions of these individuals. ${ }^{26}$

Through educational actions, the nurse should act as a facilitator of family adaptation, using scientific knowledge and combining theory and practice in order to provide clarification on the care and therapeutic resources available and to plan actions according to needs, so that patients and their families can live more harmoniously with the GD, reducing fear and anguish in their lives. ${ }^{22}$ 


\section{CONCLUSION AND IMPLICATIONS FOR PRACTICE}

Genetic diseases (GDs) had significant repercussions on the lives of the families studied, since the manifestation of the first symptoms, the discovery and confirmation of the diagnosis, and throughout follow-up, treatment in the health services and judicialization of access to medications. In this process, health services and nursing professionals have the fundamental role of providing families with access to information, and are responsible for decision making and for the organization and management of health and nursing services to meet the demands imposed on the individual and the family by the genetic disease.

The unpreparedness of health personnel and the organization of health services hinder the possibility of fully meeting the needs and demands of families and the adaptation of the family, considering the chronic nature of the GD and the possibility of clinical complications and recurrent hospitalizations.

In this context, the results of this study evidence the need for training health professionals and reorganizing care in health services. Nurses can contribute by facilitating the paths of these families, playing a key role in the process of meeting their needs, through clinical care, educational, organizational and research activities.

In addition, greater investment in the development of continuing education and training programs and new guidelines in undergraduate nursing courses are necessary. Also, it is necessary to develop new studies about nurses' knowledge on issues involving genetics/genomics and the care provided to people with GD, in order to identify the gaps in these issues in order to provide effective, direct, specific, human and quality care.

Despite of the limitations of this study, mainly related to the small number of participants, its results may support the scientific and academic areas and the practices of professionals who work directly with individuals and families with GD, as part of their living process. New research could be conducted to analyze what are the difficulties presented by health professionals in the management of genetics and genomics issues and/or to identify what are the factors that interfere in the implementation and operationalization of the National Policy on Comprehensive Care for People with Rare Diseases within the SUS and in the implementation of Health Care Networks in the three spheres of government, in relation to comprehensive care for individuals and families with genetic diseases.

\section{REFERENCES}

1. Fontinele DCSS, Silva ANS, Pereira DEWFA, Santos DB, Melo SBF, Leite AG. Doenças genéticas e inclusão escolar no estado do Rio Grande do Norte. Revista Humano Ser - UNIFACEX [Internet]. 2015; [cited 2018 jul 20]; 1(1):115-130. Available from: https://periodicos.unifacex.com. $\mathrm{br} /$ humanoser/article/view/629

2. Passos-Bueno MR, Bertola D, Horovitz DDG, Ferraz VEF, Brito LA. Genetics and genomics in Brazil: a promising future. Mol Genet Genomic Med [Internet]. 2014 jul; [cited 2018 dec 05]; 2(4):280-291. Available from: https://www.ncbi.nlm.nih.gov/pmc/articles/PMC4113268/ DOI: https://doi.org/10.1002/mgg3.95
3. Santos SMR, Duarte TR, Barroso MD, Jesus MCP. Vivências dos familiares frente á criança com fibrose cística. J Health Sci [Internet]. 2017; [cited 2019 jun 11]; 19(2):89-94. Available from: http://docs. bvsalud.org/biblioref/2017/08/847547/vivencias-dos-familiares-frentea-crianca-com-fibrose-cistica.pdf DOI: http://dx.doi.org/10.17921/24478938.2017v19n2p89-94

4. Luz GS, Silva MRS, DeMontigny F. Necessidades prioritárias referidas pelas famílias de pessoas com doenças raras. Texto Contexto - Enferm [Internet]. 2016; [cited 2018 jul 25]; 25(4):e0590015. Available from: http://www.scielo.br/scielo.php?pid=S010407072016000400311\&script=sci_abstract\&tlng=pt DOI: http://dx.doi. org/10.1590/0104-07072016000590015

5. Melo DG, Paula PK, Rodrigues SA, Avó LRDS, Germano CMR, Demarzo MMP. Genetics in primary health care and the National Policy on Comprehensive Care for People with Rare Diseases in Brazil: opportunities and challenges for professional education. J Community Genet [Internet]. 2015 jul; [cited 2018 dec 05]; 6(3):231-240. Available from: https://www.ncbi.nlm.nih.gov/pmc/articles/PMC4524835/ DOI: https://doi.org/10.1007/s12687-015-0224-6

6. Bolla BA, Fulconi SN, Baltor MRR, Dupas G. Child care with congenital anomaly: family experience. Esc Anna Nery [Internet]. 2013 jun; [cited 2019 jul 31]; 17(2):284-290. Available from: http://www.scielo.br/scielo. php?script=sci_arttext\&pid=S1414-81452013000200012\&lng=pt\&tlng =pt DOI: http://dx.doi.org/10.1590/S1414-81452013000200012

7. Melo DG, Germano CMR, Porciúncula CGG, Paiva IS, Neri JICF, Avó LRS, Néri JICF. Qualificação e provimento de médicos no contexto da Política Nacional de Atenção Integral às Pessoas com Doenças Raras no Sistema Único de Saúde (SUS). Interface (Botucatu) [Internet]. 2017; [cited 2019 jun 15]; 21(Suppl 1):120516. Available from: http://www.scielo.br/scielo.php?script=sci arttext\&pid=S1414-32832017000501205\&lng=pt\&tlng=pt DOI: http:// dx.doi.org/10.1590/1807-57622016.0211

8. Sales LAP, Lajus TBP. Aconselhamento genético em oncologia no Brasil: realidade e perspectivas. Rev Med (São Paulo) [Internet]. 2018; [cited 2019 jun 15]; 97(5):448-53. Available from: http://www.revistas. usp.br/revistadc/article/view/146568 DOI: http://dx.doi.org/10.11606/ issn.1679-9836.v97i5p448-453

9. Lopes-Júnior LC, Flória-Santos M, Ferraz VEF, Villa TCS, Palha PF, Bomfim EO, et al. Exequibilidade da atenção integral em genética clínica no sistema único de saúde: ampliando o debate. Texto Contexto - Enferm [Internet]. 2014 dec; [cited em 2019 jun 15]; 23(4):11301135. Available from: http://www.scielo.br/scielo.php?pid=S010407072014000401130\&script=sci_abstract\&tlng=pt DOI: http://dx.doi. org/10.1590/0104-07072014002120012

10. Lopes-Júnior LC, Carvalho Júnior PM, Ferraz VEF, Nascimento LC, Van Riper M, Flória-Santos M. Genetic education, knowledge and experiences between nurses and physicians in primary care in Brazil: $A$ cross-sectional study. Nurs Health Sci [Internet]. 2017 aug; [cited 2019 jun 16]; 19(1):66-74. Available from: https://onlinelibrary.wiley.com/doi/ full/10.1111/nhs.12304 DOI: https://doi.org/10.1111/nhs.12304

11. Ministério da Saúde (BR). Gabinete de Ministro. Portaria n. 199, de 30 de janeiro de 2014. Institui a Política Nacional de Atenção Integral às Pessoas com Doenças Raras, aprova as Diretrizes para Atenção Integral às Pessoas com Doenças Raras no âmbito do Sistema Único de Saúde (SUS) e institui incentivos financeiros de custeio [Internet] Brasília (DF): Ministério da Saúde. 30 jan 2014; [cited 2018 jul 15]. Available from: http://bvsms.saude.gov.br/bvs/saudelegis/gm/2014/ prt0199_30_01_2014.html

12. Flória-Santos M, Nascimento LC. Perspectivas históricas do Projeto Genoma e a evolução da enfermagem. Rev Bras Enferm [Internet]. 2006 jun; [cited 2019 jun 16]; 59(3):358-361. Available from: http://www.scielo. br/scielo.php?script=sci_arttext\&pid=S0034-71672006000300020\&lng =pt\&tlng=pt DOI: http://dx.doi.org/10.1590/S0034-71672006000300020

13. Williams JK, Feero WG, Veenstra DL, Starkweather A, Cashion AK. Considerations in Initiating Genomic Screening Programs in Health Care Systems. Nurs Outlook [Internet]. 2018 nov/dec; [cited 2019 jun 13]; 66(6):570-575. Available from: https://www.nursingoutlook.org/ article/S0029-6554(18)30179-9/fulltext DOI: https://doi.org/10.1016/j. outlook.2018.06.008 
14. Lopes-Júnior LC, Bonfim EO, Flória-Santos M. Genomics-based health care: implications for nursing. Int $\mathrm{J}$ Nurs Didactics [Internet]. 2015 feb; [cited 2018 jul 25]; 5(2):11-15. Available from: https://www. researchgate.net/publication/272888082_GenomicsBased_Health Care_Implications_for_Nursing DOI: http://dx.doi.org/10.15520/ ijnd.2015.vol5.iss02.60.11-15

15. Gil AC. Como elaborar projetos de pesquisa. $5^{\text {a }}$ ed. São Paulo: Atlas; 2010.

16. Fontanella BJB, Ricas J, Turato ER. Amostragem por saturação em pesquisas qualitativas em saúde: contribuições teóricas. Cad Saúde Pública [Internet]. 2008 jan; [cited 2019 jun 16]; 24(1):17-27. Available from: http://www.scielo.br/scielo.php?script=sci_arttext\&pid=S0102311X2008000100003 DOI: http://dx.doi.org/10.1590/S0102$311 \times 2008000100003$

17. Minayo MCS. O desafio do conhecimento: pesquisa qualitativa em saúde. São Paulo (SP): Hucitec/ABRASCO; 2010.

18. Leita MF, Gomes IP, Morais JD, Collet N. Impacto na vida de mães cuidadoras de crianças com doença crônica. Rev Enferm UERJ [Internet]. 2015; [cited 2018 jun 02]; 23(4):501-506. Available from: https://www.e-publicacoes.uerj.br/index.php/enfermagemuerj/article/ view/4966 DOI: http://dx.doi.org/10.12957/reuerj.2015.4966

19. Ministério da Saúde (BR). Gabinete do Ministro. Portaria n. 81 , de 20 de janeiro de 2009. Institui no âmbito do Sistema Único de Saúde (SUS) a Política Nacional de Atenção Integral em Genética Clínica [Internet]. Brasília (DF): Ministério de Saúde. 20 jan 2009; [cited 2018 jul 15]. Available from: http://bvsms.saude.gov.br/bvs/saudelegis/gm/2009/ prt0081_20_01_2009.html

20. Ministério da Saúde (BR). Secretaria de Atenção à Saúde. Portaria n. 55, de 24 de fevereiro de 1999. Dispõe sobre a rotina do Tratamento Fora de Domicilio no Sistema Único de Saúde - SUS, com inclusão dos procedimentos específicos na tabela de procedimentos do Sistema de Informações Ambulatoriais do SIA/SUS e dá outras providências [Internet]. Brasília (DF): Ministério da Saúde; 24 fev 1999; [cited 2018 jul 15]. Available from: http://bvsms.saude.gov.br/bvs/saudelegis/ sas/1999/prt0055_24_02_1999.html
21. Luz GS, Silva MRS, DeMontigny F. Doenças raras: itinerário diagnóstico e terapêutico das famílias de pessoas afetadas. Acta Paul Enferm [Internet]. 2015 aug; [cited 2018 aug 02]; 28(5):395400. Available from: http://www.scielo.br/scielo.php?script=sci arttext\&pid=S0103-21002015000500395\&lng=pt\&tlng=pt DOI: http:// dx.doi.org/10.1590/1982-0194201500067

22. Machado AN, Nóbrega VM, Silva MEA, França DBL, Reichert APS, Collet N. Doença crônica infantojuvenil: vínculo profissional-família para a promoção do apoio social. Rev Gaúch Enferm [Internet]. 2018; [cited 2018 aug 08]; 39:e2017-0290. Available from: http://www.scielo.br/ scielo.php?script=sci_arttext\&pid=S1983-14472018000100434\&lng =pt\&tlng=pt DOI: http://dx.doi.org/10.1590/1983-1447.2018.2017-0290

23. Leite IC, Bastos PRHO. Judicialização da saúde: aspectos legais e impactos orçamentários. Argum [Internet]. 2018; [cited 2019 jun 15]; 10(1):102-117. Available from: http://periodicos.ufes.br/argumentum/ article/view/18659 DOI: https://doi.org/10.18315/argumentum. v10i1.18659

24. Vieira DKR, Favoreto CAO. Narrativas em saúde: refletindo sobre o cuidado à pessoa com deficiência e doença genética no Sistema Único de Saúde (SUS). Interface (Botucatu) [Internet]. 2016 mar; [cited 2019 jun 15]; 20(56):89-98. Available from: http://www.scielo.br/scielo. php?script=sci_arttext\&pid=S1414-32832016000100089\&lng=pt\&tln g=pt DOI: http://dx.doi.org/10.1590/1807-57622015.0203

25. Lima MADFD, Gilbert ACB, Horovitz DDG. Redes de tratamento e as associações de pacientes com doenças raras. Ciênc Saúde Coletiva [Internet]. 2018 oct; [cited 2018 aug 06]; 23(10):32473256. Available from: http://www.scielo.br/scielo.php?script=sci arttext\&pid=S1413-81232018001003247\&lng=pt\&tlng=pt DOI: http:// dx.doi.org/10.1590/1413-812320182310.14762018

26. Almeida MM, Santos MS, Silva FWT. Nursing care in Sickle Cell Disease in the Family Health Strategy. J Res Fundam Care [Internet]. 2018; [cited 2018 aug 14]; 10(1):36-45. Available from: http://www.seer.unirio.br/ index.php/cuidadofundamental/article/view/5966 DOI: http://dx.doi. org/10.9789/2175-5361.2018.v10i1.36-45

\footnotetext{
${ }^{a}$ Article extracted from the thesis entitled The process of living in families with children with genetic disease: coping strategies, presented to the Nursing Graduate Program of the School of Nursing (EEnf) of the Federal University of Rio Grande (FURG), 2018, by Laura Helena Gerber Franciscatto oriented by Mara Regina Santos da Silva.
} 